\title{
PENERAPAN PEMBELAJARAN JARAK JAUH BERBASIS MICROSOFT SWAY UNTUK MENINGKATKAN KEMAMPUAN PEMECAHAN MASALAH MATEMATIS
}

\author{
Anwar Sadat ${ }^{1}$, Wati Herliyani ${ }^{2}$ Handri Wijaya ${ }^{3}$, \\ 1,2,3 Jurusan Pendidikan Matematika FKIP Universitas Mandiri \\ 1'mocsadatanwar@gmail.com, 2watiherliyani6698@gmail.com, \\ 3handriwijaya82@gmail.com
}

\begin{abstract}
This research is motivated by the low mathematical problem solving ability of students in learning mathematics caused by the lack of examples that are applied in students' daily lives. To overcome these problems, teachers have a very important role in achieving student learning success. However, currently there is a COVID-19 pandemic which has an impact on the education sector which requires the temporary closure of educational institutions, resulting in learning to be carried out through distance learning. One of the distance learning that can be applied to create effective learning conditions to achieve the expected goals, especially in learning mathematics, is distance learning based on Microsoft Sway. The purpose of this study was to determine the mathematical problem solving ability of students, as well as to determine the independence of students' learning after obtaining mathematics learning using distance learning based on Microsoft Sway. This research was carried out using the ex post facto method. The sample of this study was class VII G MTsN 3 Subang which amounted to 32 people, but because the sample did not respond to the given test (missing sample), the sample became nine people. The instrument used in the form of a mathematical problem solving ability test with four questions and a non-test used in the form of a learning independence questionnaire consisting of 30 statements. Calculation of data processing using Statistical Product and Solution Services (SPSS) 17.0 for windows software with a significance level of $\alpha=0.05$. The results showed that the increase in students' mathematical problem solving skills using Microsoft Swaybased distance learning was at least in the category, and students' learning independence towards mathematics learning using Microsoft Sway-based distance learning was in the independent category.
\end{abstract}

Keywords: Distance Learning, Mathematical Problem Solving, Microsoft Sway

\section{ABSTRAK}

Penelitian ini dilatar belakangi oleh rendahnya kemampuan pemecahan masalah matematis peserta didik dalam belajar matematika yang disebabkan oleh kurangnya contoh yang diaplikasikan dalam kehidupan sehari-hari peserta didik. Untuk mengatasi masalah tersebut, guru memiliki peranan yang amat penting dalam mencapai keberhasilan pembelajaran peserta didik. Namun saat ini sedang terjadi pandemi COVID-19 yang berdampak pada sektor pendidikan yang mengharuskan penutupan sementara lembaga pendidikan,mengakibatkan 
pembelajaran dilaksanakan melalui pembelajaran jarak jauh. Salah satu pembelajaran jarak jauh yang dapat diterapkan guna menciptakan kondisi belajar yang efektif untuk mencapai tujuan yang diharapkan khususnya dalam pembelajaran matematika yaitu dengan pembelajaran jarak jauh berbasis microsoft sway. Tujuan penelitian ini adalah untuk mengetahui kemampuan pemecahan masalah matematis peserta didik, serta mengetahui kemandirian belajar peserta didik setelah memperoleh pembelajaran matematika menggunakan pembelajaran jarak jauh berbasis microsoft sway. Penelitian ini dilaksanakan dengan metode ex post facto. Sampel penelitian ini adalah kelas VII G MTsN 3 Subang yang berjumlah 32 orang, namun karena sampel tidak memberikan respon terhadap test yang diberikan (sampel hilang) maka sampelnya menjadi berjumlah sembilan orang. Instrumen yang digunakan berupa tes kemampuan pemecahan masalah matematis sebanyak empat butir soal dan non tes yang digunakan berupa angket kemandirian belajar yang terdiri dari 30 butir pernyataan. Perhitungan pengolahan data menggunakan software Statistical Product and Solution Services (SPSS) 17.0 for windows dengan pengambilan taraf signifikansi $\alpha=0,05$. Hasil penelitian menunjukkan bahwa peningkatan kemampuan pemecahan masalah matematis peserta didik menggunakan pembelajaran jarak jauh berbasis microsoft sway paling sedikit pada kategori sedang, dan kemandirian belajar peserta didik terhadap pembelajaran matematika menggunakan pembelajaran jarak jauh berbasis Microsoft sway berada pada kategori mandiri.

Kata kunci: Microsoft Sway, Pembelajaran Jarak Jauh, Pemecahan Masalah Matematis.

\section{A. Pendahuluan}

Pendidikan merupakan kunci
masa depan yang memegang peranan penting untuk menjamin perkembangan dan kelangsungan hidup manusia sehingga terjadi peningkatan kualitas sumber daya manusia (Sayfuddin, 2019:1).

Menurut Horne (Listyarti, 2012:2), pendidikan adalah proses yang terjadi secara abadi dari penyesuaian yang lebih tinggi bagi manusia yang telah berkembang fisik dan mentalnya, yang bebas dan sadar kepada Tuhannya, sehingga terwujud intelektual, emosional dan kemanusiaan itu sendiri. Listyarti (2012:4) mengungkapkan bahwa pendidikan adalah proses mengubah aspek pengetahuan, sikap dan keterampilan manusia agar senantiasa menjadi lebih baik. Pendidikan menjadi jembatan yang harus dilalui agar dapat 
membantu manusia menuju "perubahan".

\section{Perubahan dan kemajuan} kehidupan sosial pada era globalisasi ini adalah salah satu tantangan dalam dunia pendidikan. Dunia pendidikan dituntut mempersiapkan peserta didik untuk menjadi manusia yang berkualitas, mampu bersaing dengan kemajuan IPTEK, mempunyai kesiapan mental, kesiapan kemampuan (skill), dan mampu menyiapkan manusia yang berakhlak mulia (Bakhri, 2018). Selaras dengan tuntutan negara mengenai fungsi dan tujuan pendidikan dalam UU no. 20 tahun 2003 pasal 3 bahwa fungsi pendidikan nasional adalah mengembangkan kemampuan dan membentuk watak serta peradaban bangsa yang bermartabat dalam rangka mencerdaskan kehidupan bangsa, bertujuan untuk mengembangkan potensi peserta didik agar menjadi manusia yang beriman dan bertakwa kepada Tuhan Yang Maha Esa, berakhlak mulia, sehat, berilmu, cakap, kreatif, mandiri, dan menjadi warga negara yang demokrasi serta bertanggung jawab.
Sebagai upaya menghadapi tuntutan era globalisasi, pendidikan formal hadir menjadi bagian penting bagi peserta didik. Dalam pendidikan formal terdapat jenjang pendidikan yang jelas, mulai dari pendidikan dasar, menengah, hingga pendidikan tinggi. Berkembangnya lembaga pendidikan dalam bentuk lembaga pendidikan sekolah menuntut adanya kurikulum yang dirancang dan dikembangkan secara tertulis.

Kurikulum adalah seperangkat rencana dan pengaturan mengenai tujuan, isi, dan bahan pelajaran, serta cara yang digunakan sebagai pedoman penyelenggaraan kegiatan pembelajaran untuk mencapai tujuan pendidikan tertentu (UU no.19 tahun 2005). Saat ini, kurikulum yang digunakan lembaga pendidikan Indonesia adalah kurikulum 2013. Zaini (2015:25) menyebutkan bahwa dalam kurikulum 2013 konten materi pelajarannya dikemas dalam bentuk tematik dan salah satu karakteristiknya yaitu menekankan pada aspek kognitif, afektif, dan psikomotorik.

Dalam struktur kurikulum 2013 pada semua jenjang pendidikan, mata pelajaran matematika merupakan mata pelajaran 
wajib. Menurut Ali, dkk (2014:48) matematika adalah salah satu mata pelajaran yang dapat mengembangkan kemampuan dan ketepatan berpikir. Selaras dengan itu, Susanto (2013) mengemukakan bahwa matematika merupakan salah satu disiplin ilmu yang dapat meningkatkan kemampuan berpikir dan menyuarakan pendapat, memberikan kontribusi dalam menyelesaikan masalah sehari-hari dan memberikan dukungan dalam perkembangan IPTEK. Maka, matematika sebagai ilmu dasar perlu dikuasai dengan baik oleh peserta didik.

Menurut National Council of Teacher of Mathematics (NCTM) (Damayanti, 2019) Kemampuan dasar matematis yang harus dikuasai peserta didik melalui pembelajaran matematika yaitu (1) Komunikasi (communication);

(2) penalaran (reasoning); (3) koneksi (connection) (4) representasi (representation); (5) pemecahan masalah (problem solving). Menurut Polya (Wardhani, 2010) pemecahan masalah adalah usaha menemukan solusi terhadap kesulitan yang dihadapi guna mencapai tujuan yang tidak mudah untuk diperoleh. Sedangkan menurut
Robert L.Solso (Siti dan Hana, 2015) pemecahan masalah adalah suatu pemikiran terarah secara langsung guna menemukan solusi atau jalan keluar dari masalah yang spesifik. Dari kedua pengertian di atas, dapat disimpulkan bahwa pemecahan masalah adalah suatu proses berpikir secara terarah untuk menentukan apa yang harus dilakukan guna mengatasi suatu masalah.

Branca (Adhar, 2012) mengungkapkan bahwa kemampuan pemecahan masalah merupakan jantungnya matematika. Selaras dengan National Council of Teacher of Mathematics (NCTM) (Damayanti, 2019) yang menyebutkan bahwa kemampuan pemecahan masalah sebagai bagian integral dalam pembelajaran matematika. Kemampuan pemecahan masalah menjadi kemampuan yang penting dan paling ditekankan untuk dimiliki agar peserta didik terbiasa dalam menghadapi berbagai masalah dalam matematika, dalam bidang studi lain juga dalam kehidupan sehari-hari.

Sebagai upaya menguatkan perihal pentingnya kemampuan pemecahan masalah, Suryadi dkk (Marlisa, 2015) dengan sponsor Japan International Cooperation 
Agency (JICA) melakukan survey "Current Situation on Mathematics and Science Education in Bandung" dengan memperoleh hasil bahwa pemecahan masalah adalah salah satu kemampuan yang paling penting bagi guru dan peserta didik dalam semua jenjang pendidikan.

Peran guru teramat penting dalam menentukan keberhasilan proses pembelajaran (Sarbiyono, 2015). Maka untuk mencapai keberhasilan tersebut, hubungan interaksi guru dan peserta didik juga turut mempengaruhi proses pembelajarnnya.

Guru sejatinya bukanlah satusatunya sumber belajar, guru harus menjadi fasilitator, sutradara dan penulis skenario (Listyarti, 2012:15). Skenario yang dimaksud ini dirancang oleh guru dalam bentuk Rencana Pelaksanaan Pembelajaran (RPP), kemudian dilaksanakan oleh guru dan peserta didik, dimana guru sebagai sutradara dan pesera didik sebagai aktor. Peserta didik dapat memilih peran sebagai aktor utama, aktor pendamping atau sebagai figuran saja. Guru harus siap berubah menjadi motivator, dan inspirator, bukan guru yang orator, apalagi otoriter dan dominan.
Namun saat ini dunia sedang dilanda wabah penyakit yang disebabkan sebuah virus yang bernama Corona atau dikenal dengan istilah COVID-19 (Coronavirus Disease-19). COVID-19 adalah penyakit jenis baru yang belum pernah diidentifikasi sebelumnya dalam tubuh manusia. Indonesia adalah salah satu negara yang terdampak COVID-19. Penyebaran virus COVID-19 pada awalnya sangat berdampak pada dunia ekonomi yang mulai lesu, tetapi kini dampaknya dirasakan juga oleh dunia pendidikan. Kebijakan yang diambil oleh banyak negara termasuk Indonesia dengan membatasi seluruh aktivitas yang melibatkan perkumpulan banyak orang. Pemerintah sudah mengimbau agar bekerja, belajar, dan beribadah dari rumah untuk menekan angka pasien yang terpapar COVID-19.

Pada tanggal 24 Maret 2020 Menteri Pendidikan dan Kebudayaan Republik Indonesia mengeluarkan Surat Edaran Nomor 4 Tahun 2020 tentang Pelaksanaan Kebijakan Pendidikan dalam Masa Darurat Penyebaran COVID. Dalam Surat Edaran tersebut dijelaskan bahwa proses belajar dilaksanakan dirumah untuk memberikan pengalaman 
belajar bermakna bagi peserta didik melalui pembelajaran jarak jauh.

Pembelajaran jarak jauh merupakan pembelajaran yang peserta didiknya terpisah dari guru serta pembelajarannya menggunakan berbagai sumber belajar melalui teknologi komunikasi, data, serta media lainnya. Menurut Munir (2009) pembelajaran jarak jauh adalah ketika proses pembelajaran tidak terjadinya kontak dalam bentuk tatap muka langsung antara pengajar dan peserta didik. Jadi pada dasarnya, pembelajaran jarak jauh yang dilakukan tidak terbatas ruang dan waktu, tapi perlu diingat bahwa pembelajaran jarak jauh juga harus memperhatikan kesiapan peserta didik dan guru dalam merancang pembelajaran jarak jauh.

\section{Bermacam}

media

pembelajaran jarak jauh digunakan guna membantu tercapainya tujuan pendidikan sebagai pengganti pembelajaran dikelas secara langsung. Media pembelajaran jarak jauh secara offline misalnya media worksheet. Sedangkan media pembelajaran jarak jauh secara online misalnya e-learning, aplikasi zoom, smart classroom, youtube, microsoft sway, whatsApp ataupun media sosial lainnya. Dalam penelitian ini media pembelajaran jarak jauh yang digunakan adalah media pembelajaran secara online yaitu microsoft sway. Melalui pembelajaran jarak jauh ini diharapkan peserta didik tetap dapat menumbuhkan pendidikan karakter, seperti kreativitas, kejujuran, percaya diri, tolong menolong, saling menghargai, dan kemandirian dalam belajar.

Menurut Tirtahardja (Silvia dan Edy, 2017) kemandirian dalam belajar adalah aktivitas belajar yang terjadi atas dasar kemauan sendiri, pilihan sendiri, dan tanggung jawab sendiri terhadap pembelajaran. Kemandirian belajar adalah suatu keterampilan belajar yang dalam proses belajar individu didorong, dikendalikan dan dinilai oleh diri individu itu sendiri (Lilik dkk, 2013:64). Sehingga, peserta didik mengatur pembelajarannya sendiri dengan mengaktifkan kognitif, afektif dan perilakunya yang ada pada dirinya sehingga tercapai tujuan belajar yang diinginkan.

Perlunya pengembangan kemandirian belajar pada peserta didik bertujuan untuk menunjang keberhasilan dalam proses 
pembelajaran dan memenuhi tuntutan dimasa pandemi ini. Maka berdasarkan latar belakang tersebut, penelitian ini berjudul "Penerapan Pembelajaran Jarak Jauh (PJJ) Berbasis Microsoft Sway untuk Meningkatkan Kemampuan Pemecahan Masalah Matematis Peserta Didik".

\section{Kemampuan Pemecahan} Masalah Matematis

Menurut Polya (Wardhani,
2010) pemecahan masalah
adalah usaha menemukan solusi
terhadap kesulitan yang dihadapi
guna mencapai tujuan yang tidak
mudah untuk diperoleh. Sedangkan
menurut Robert L.Solso (Siti dan
Hana, 2014) pemecahan masalah
adalah suatu pemikiran terarah
secara langsung guna menemukan
solusi atau jalan keluar dari masalah
yang spesifik. Branca (Adhar, 2012)
mengungkapkan bahwa kemampuan
pemecahan masalah merupakan
jantungnya matematika. Selaras
dengan National Council of Teacher
of Mathematics (NCTM) (Damayanti,
2019) yang menyebutkan bahwa
kemampuan pemecahan masalah
sebagai bagian integral dalam
pembelajaran matematika.

Ruseffendi (Adhar, 2012) menyebutkan bahwa kamampuan pemecahan masalah amat penting tidak hanya untuk yang akan mendalami atau mempelajarinya saja, namun juga bagi mereka yang akan mengaplikasikannya dalam bidang studi lain dan kehidupan sehari-hari. Kemampuan pemecahan masalah menjadi kemampuan yang penting dan paling ditekankan untuk dimiliki agar peserta didik terbiasa dalam menghadapi berbagai masalah dalam matematika, dalam bidang studi lain juga dalam kehidupan sehari-hari.

Berdasarkan uraian di atas, dapat disimpulkan bahwa pemecahan masalah adalah suatu proses berpikir secara terarah untuk menentukan apa yang harus dilakukan guna mengatasi suatu masalah.

Soemarmo dan Hendriana (2014:23) mengemukakan indikator pemecahan masalah matematis yaitu:

a. Mengidentifikasi unsur yang diketahui, yang ditanyakan, dan kecukupan unsur yang diperlukan

b. Merumuskan masalah matematis atau menyusun model matematis

c. Menerapkan strategi untuk menyelesaikan masalah 
d. Menjelaskan atau menginterprtasi hasil penyelesaian masalah.

\section{Menurut Polya (Wardhani,} 2010) untuk memecahkan suatu masalah terdapat empat langkah yang diperlukan, yaitu :

a. Memahami masalah, kegiatan pada langkah ini yaitu menentukan data apa yang diketahui, yang diperlukan dan yang harus dipenuhi, kemudian menyatakan kembali masalah secara operasional.

b. Membuat rencana pemecahan masalah, kegiatan yang dilakukan adalah mencoba mencari dan mengingat masalah yang pernah diselesaikan yang memiliki kemiripan dengan masalah yang sedang dihadapi, menyusun pola dan aturan, menyusun prosedur penyelesaian.

c. Melaksanakan

rencana

pemecahan masalah, kegiatan yang dilakukan yaitu melaksanakan prosedur yang telah dibuat dalam proses perencanaan untuk menyelesaikan masalah.

d. Memeriksa kembali prosedur dan hasil penyelesainnya, kegiatan yang dilakukan yaitu menganalisis dan mengevaluasi apakah prosedur dan hasil yang diperoleh sudah benar, apakah prosedur yang diterapkan dapat diterapkan juga pada soal lain yang sejenis atau apakah prosedur tersebut dapat digeneralisasikan.

\section{Pembelajaran Jarak Jauh Berbasis Microsoft Sway}

Pembelajaran jarak jauh merupakan pembelajaran yang peserta didiknya terpisah dari guru dan serta pembelajarannya menggunakan berbagai sumber melalui teknologi komunikasi, data dan media lainnya. Menurut Munir (2009) pembelajaran jarak jauh adalah ketika proses pembelajaran tidak terjadinya kontak dalam bentuk tatap muka langsung antara pengajar dan peserta didik. Komunikasi tetap berlangsung secara dua arah yang dijembatani dengan media. Media yang bisa digunakan seperti komputer, televisi, radio, telepon, internet, video, dan sebagainya. Media lain yang biasa digunakan secara offline adalah dengan media penugasan dan worksheet, sedangkan media online misalnya elearning, aplikasi zoom, smart classroom, youtube, microsoft sway, whatsApp ataupun media sosial lainnya. 
Didaktik : Jurnal IImiah PGSD STKIP Subang, ISSN Cetak : 2477-5673 ISSN Online : 2614-722X Volume VI Nomor 02, Desember 2021

Microsoft sway merupakan aplikasi yang dapat menampilkan teks, gambar, video dan link soal (kuis dari aplikasi lain) menjadi lebih menarik dan mudah digunakan bagi seorang guru yang menginginkan pembelajaran menjadi lebih mudah dan dapat dipahami peserta didik.

\section{Hasil Penelitian dan}

\section{Pembahasan}

\section{Kemampuan}

Pemecahan

Masalah Matematis

Data yang dihasilkan pada deskripsi kemampuan pemecahan masalah matematis merupakan data hasil pretest dan hasil posttest peserta didik. Analisis data deskriptif menggunakan Software SPSS 17.0 for Windows. Hasil analisis data disajikan pada Tabel 4.1.

Tabel 4.1

Analisis Deskriptif Tes

Kemampuan Pemecahan Masalah Matematis

\begin{tabular}{|c|c|c|}
\hline & Pretest & Posttest \\
\hline $\begin{array}{c}\text { Banyak } \\
\text { sampel }\end{array}$ & 9 & 9 \\
\hline $\begin{array}{c}\text { Skor } \\
\text { Terendah }\end{array}$ & 0 & 17 \\
\hline $\begin{array}{c}\text { Skor } \\
\text { Tertinggi }\end{array}$ & 16 & 40 \\
\hline Mean & 8,78 & 30,78 \\
\hline $\begin{array}{c}\text { Standar } \\
\text { Deviasi }\end{array}$ & 6,61 & 7,84 \\
\hline
\end{tabular}

Tabel 4.1 memperlihatkan bahwa dari semua peserta didik, skor terendah pada pretest yaitu 0 sedangkan skor terendah pada posttest yaitu 17. Skor tertinggi pada pretest yaitu 16 sedangkan skor tertinggi saat posttest yaitu 40. Rata-rata skor pada pretest yaitu 8,78 sedangkan rata-rata skor pada posttest yaitu 30,78 . Standar deviasi pada pretest yaitu 6,61 sedangkan standar deviasi pada posttest yaitu 7,84 .

Kemudian, Analisis data NGain untuk mengetahui kualitas peningkatan kemampuan pemecahan masalah matematis peserta didik ditunjukkan pada Tabel 4.2.

Tabel 4.2 Analisis Data N-Gain Kemampuan Pemecahan Masalah Matematis

\begin{tabular}{|c|c|}
\hline & N-Gain \\
\hline Banyak sampel & 9 \\
\hline Skor Terendah & 0,15 \\
\hline Skor Tertinggi & 1 \\
\hline Mean & 0,69 \\
\hline Standar Deviasi & 0,28 \\
\hline
\end{tabular}

Tabel 4.2 menunjukkan bahwa rata-rata data $\mathrm{N}$-Gain dari sembilan peserta didik adalah 0,69 yang berarti memiliki kriteria sedang.

Selanjutnya hasil uji normalitas data $\mathrm{N}$-Gain kemampuan pemecahan masalah matematis peserta didik menggunakan Software 
SPSS 17.0 for windows disajikan pada Tabel 4.3.

\section{Tabel 4.3}

Hasil Uji Normalitas N-Gain

\begin{tabular}{|c|c|c|c|}
\hline & \multicolumn{3}{|c|}{ Shapiro-Wilk } \\
\hline & Statistic & Df & Sig. \\
\hline N-Gain & .904 & 9 & .276 \\
\hline
\end{tabular}

\section{Berdasarkan}

hasil uji

Shapiro-Wilk, nilai signifikansi data $\mathrm{N}$-Gain $0,276>0,05$ maka $\mathrm{H}_{0}$ diterima. Artinya bahwa data N-Gain kemampuan pemecahan masalah matematis ini berdistribusi normal.

One sample-t test digunakan untuk menguji apakah peningkatan kemampuan pemecahan masalah matematis peserta didik paling sedikit pada kategori sedang signifikan atau tidak, dengan rumusan hipotesis sebagai berikut:

$\mathrm{H}_{0}: \mu \geq 0,30$

$\mathrm{H}_{1}: \mu<0,30$

Dengan nilai

$$
\begin{aligned}
t_{\text {hitung }}= & \frac{(\bar{x}-\mu) \sqrt{n}}{s} \\
& =\frac{(0,69-0,30) \sqrt{9}}{0,28}=4,18
\end{aligned}
$$

Dan

$$
t_{\text {tabel }}=t_{0,05}(D K=8)=1,860
$$

Karena $\quad t_{\text {hitung }}>-t_{\text {tabel }} \quad$ (uji fihak kiri) maka $\mathrm{H}_{0}$ diterima, artinya, "peningkatan kemampuan pemecahan masalah matematis peserta didik menggunakan pembelajaran jarak jauh berbasis microsoft sway paling sedikit pada kategori sedang".

\section{Kemandirian Belajar Siwa}

Pengolahan data kualitatif dalam penelitian ini adalah pengolahan data untuk angket kemandirian belajar. Dalam penelitian ini peserta didik diminta untuk membaca secara seksama setiap pernyataan yang disajikan dalam angket, kemudian diminta untuk merespon atau memberikan tanggapan terhadap pernyataan-pernyataan tersebut.

Angket yang diberikan adalah 30 butir pernyataan dimana terdiri dari 15 pernyataan positif dan 15 pernyataan negatif.

Setelah dianalisis secara deskriptif, rata-rata untuk pernyataan positif tiap butir dalam angket kemandirian belajar adalah 3,95 yang jika dipersentasekan yaitu $79 \%$. Ini menunjukkan bahwa tingkat kemandirian belajar peserta didik setelah proses pembelajaran jarak jauh berbasis microsoft sway berada pada kategori mandiri.

Rata-rata pernyataan negatif tiap butir dalam angket kemandirian belajar adalah 4,44 yang jika dipersentasekan yaitu $88,8 \%$. Ini menunjukkan bahwa tingkat kemandirian peserta didik setelah 
proses pembelajaran jarak jauh berbasis microsoft sway berada pada kategori mandiri.

Bila dihitung rata-rata dari persentase pernyataan positif dan negatif diperoleh $83,9 \%$. Berdasarkan hasil rata-rata persentase yang diperoleh tersebut dapat disimpulkan bahwa kemandirian belajar peserta didik setelah proses pembelajaran jarak jauh berbasis microsoft sway berada pada kategori mandiri.

\section{Simpulan}

Berdasarkan seluruh rangkaian penelitian yang telah dilakukan, mulai dari langkah persiapan, pelaksanaan, hingga analisis data, maka dapat dikemukaan kesimpulan sebagai berikut.

1. Peningkatan kemampuan pemecahan masalah matematis peserta didik yang mendapat pembelajaran jarak jauh berbasis microsoft sway paling sedikit berada pada kategori sedang ditolak atau tidak cukup bukti untuk diterima pada signifikansi $5 \%$.

2. Kemandirian belajar peserta didik setelah pembelajaran matematika menggunakan pembelajaran jarak jauh berbasis microsoft sway berada pada kategori mandiri.

Berdasarkan penelitian yang telah dilakukan, ada beberapa saran yang ingin disampaikan, yaitu:

a. Berdasarkan temuan yang didapat dalam penelitian ini, untuk penggunaan pembelajaran jarak jauh berbasis microsoft sway harus memiliki sarana dan prasaran yang memadai. Sarana dan prasarana yang harus ada yaitu telepon genggam, kartu kuota, dan jaringan internet yang bagus, mengingat bahwa respon peserta didik dalam penelitian ini kurang karena kurangnya sarana dan prasarana yang memadai tersebut.

b. Bagi guru, diharapkan guru-guru mampu memberikan inovasi bagi peserta didik, agar peserta didik lebih terdorong dan tidak bosan mengikuti pembelajaran yang ada di sekolah. Untuk bisa menggunakan microsoft sway guru harus memiliki kreatifitas yang tinggi, harus mampu menyampaikan isi materi dan tujuan pembelajaran dalam microsoft sway sehingga dapat menarik minat dan motivasi peserta didik. 


\section{DAFTAR PUSTAKA}

Achmad, Farida, I.. (2008). Pengaruh Kemandirian Belajar dan Disiplin Belajar Terhadap Prestasi Belajar Siklus Akuntansi Siswa Kelas $X$ SMK Negeri 7 Yogyakarta Tahun Ajaran 2007/2008. [Online]. https://repository.stitradenwijaya.ac id $>\ldots$ PDF. Diakses pada tanggal 28 Juli 2020

Adhar. (2012). Pembelajaran Matematika dengan Metode Penemuan Terbimbing untuk Meningkatkan Kemampuan Representasi dan Pemecahan Masalah Matematis Siswa SMP. Vol.13 No.2. [Online]. Tersedia: https://jurnal.upi.edu. Diakses pada tanggal 28 Juli 2020

Ali, dkk. (2014). Perencanaan dan Strategi Pembelajaran Matematika. Jakarta: PT Raja Grafindo Persada

Arikunto, S. (2006). Prosedur Penelitian Suatu Pendekatan Praktek. Jakarta: PT. Rineka Cipta

Arikunto, S. (2010). Prosedur Penelitian. Jakarta: Rineka Cipta

Arikunto, S. (2017). Pengembangan Instrumen Penelitian dan Penilaian Program. Yogyakarta: Pustaka Belajar

Bakhri, S. (2018). Pendidikan Global dan Globalisasi Pendidikan (Prosiding Seminar Nasional Pendidikan Era Revolusi). Vol.1 No.1
Bistari BsY, (2010), Pengembangan Kemandirian Belajar Berbasis Nilai untuk Meningkatkan Komunikasi Matematik, Jurnal Pendidikan Matematika dan IPA FKIP Universitas Tanjungpura, Vol 1, No.1

Damayanti. (2019). Penerapan Pendekatan Open-Ended terhadap Kemampuan Pemecahan Masalah Matematika Siswa di SMPN 17 Palembang. Skripsi. Universitas Sriwijaya

Darmawan. (2020). Modul Sistem Pembelajaran PJJ. Klinik Pengembangan Pendidikan Jarak Jauh. LP3M. Universitas Udayana.

Dwi, S. (2012). Pengaruh Model Pembelajaran Matematika Realistik terhadap Kemampuan Pemecahan Masalah Matematika Siswa SMP. Skripsi. [Online]. Tersedia: http://repository.unpas.ac.id

Fifit, N, Farida, dan lip, S. (2019). Analisis Kemampuan Pemecahan Masalah Matematis: Dampak Blended Learning Menggunakan Edmodo. Jurnal; Matematika, 2 (2), 2019, 173-180. Universitas Islam Negeri Raden Intan Lampung. [Online]. Tersedia: http://ejournal.radenintan.ac.id/ind ex.php/desimal/index. Diakses pada tanggal 22 November 2020

Hartono, Y. (2014). Matematika Strategi Pemecahan Masalah. Yogyakarta: Graha IImu 
Irfan dan Syarif. (2018). Model Pembelajaran PPS (Problem Posing dan Solving): CV Jejak

Isbaniah, F. (2020). Pedoman Pencegahan Pengendalian Coronavirus Disease (COVID-19). Jakarta. Kementerian Kesehatan RI.

Labibah, U. (2016). Meningkatkan Kemampuan Pemecahan Masalah Menggunakan Pendekatan Pembelajaran Pendidikan Matematika Realistik Indonesia (PMRI) pada Materi Himpunan Siswa Kelas VII MTs Tanbihul Ghofilin Tahun Pelajaran 2015/2016. [Online]. Tersedia: https://core.ac.uk/download/pdf/80 820731. Diakses 9 Agustus 2020

Lestari, K.E. dan Yudhanegara, M. R. (2015). Penelitian Pendidikan Matematika. Bandung: PT Reflika Aditama

Lia, Y. (2013). Managemen Pendidikan. Yogyakarta: PT Reflika Aditama.

Lilik, S, Djannah,W, dan Wagimin. (2013). Tingkat Penguasaan SelfRegulated Learning Skills ditinjau dari Segi Prestasi Belajar dan Lama Studi pada Mahasiswa FKIP UNS. Jurnal Conselium, Vol.1 No.1

Listyarti, R. (2012). Pendidikan Karakter Dalam Metode Aktif, Inovatif Dan Kreatif. Jakarta: Erlangga Group
Marlisa, I. (2015). Pengaruh Strategi React ditinjau dari Gaya Kognitif terhadap Pemecahan Masalah, Prestasi Belajar, dan Apresiasi Siswa terhadap Matematika. Jurnal Riset Pendidikan Matematika No.2 Vol.2

Munir. (2009). Pembelajaran Jarak Jauh Berbasis Teknologi Informasi dan komunikasi. Alfabeta. Bandung. [Online]. Tersedia: https://file.upi.edu/Direktori/FPMIP A/PRODI. ILMU KOMPUTER/196 603252001121MUNIR/BUKU/PEM BELAJARAN\%20JARAK\%20JAUH \%20BERBASIS\%20TEKNOLOGI \%20INFORMASI\%20DAN\%20KO MUNIKASI\%20\%28TIK\%29.pdf. Diakses pada tanggal 7 Oktober $\underline{2020}$

Rahmawati, F. (2013). Pengaruh pendekatan Realistik Matematika dalam Meningkatkan Kemampuan Matematis Siswa Sekolah Dasar. Makalah Seminar Semirata. Lampung. Universitas Lampung

Ramdhani, Sendi. (2012). Pembelajaran Matematika dengan Pendekatan Problem Posing untuk Meningkatkan Kemampuan Pemecahan Masalah dan Koneksi Matematis Siswa. [Online]. Tersedia: https://respository.upi.edu. diakses pada tanggal 10 Agustus 2020

Rohmyni. (2020). Kelebihan dan Kekurangan PJJ di Masa Pandemi Covid-19. [Online]. Tersedia: https://kumparan.com/frida- 
rohmyni/kelebihan-dan-

kekurangan-pij-di-masa-pandemicovid-19-1tfqW5fo82o/full. diakses pada tanggal 7 Oktober 2020

Salmiah. (2020). Kendala yang dihadapi Murid dalam Pelaksanaan Pembelajaran Jarak Jauh di Masa Pandemi. [Online]. Tersedia: https://gg.gg/mth72. Diakses pada tanggal 31 Oktober 2020

Sarbiyono. (2015). Penerapan Pendekatan Matematika Realistik terhadap Kemampuan Pemahaman Konsep dan Kemampuan Pemecahan Masalah Matematis Tahun Pelajaran 20142015. Jakarta: Universitas Terbuka

Sayfuddin, A. (2019). Pengaruh Pendekatan Matematika Realistik Indonesia (PMRI) Berbantu Alat Peraga Edukatif Terhadap Pemecahan Masalah Matematis di Kelas IV SDN 14 WAY Serdang Mesuji. Skripsi: UIN Raden Intan Lampung

Septiana, F. (2017). Efektivitas Penerapan Pendekatan Pendidikan Matematika Realistik (PMRI) terhadap Kemampuan Pemecahan Masalah Matematis ditinjau dari Multiple Inteligences Siswa Kelas VII SMP YPI Braja Selebah Lampung Timur Tahun Ajaran 2017/2018. Skripsi. UIN Raden Intan Lampung

Setyawati Vilda. (2013). T-Test. [Online]. Tersedia: https: //dinus.ac.id/repository/docs/ajar/fil e 2013-09-

16 TEST LENGKAP.ppt. Diakses pada tanggal 15 Oktober 2020

Silvia dan Edy. (2017). Jurnal. Kemandirian Belajar dalam Memaksimalkan Pembelajaran. Medan: ResearchGade.

Siti dan Hana. (2015). Kemampuan Pemecahan Masalah Matematis Siswa pada Pembelajaran Matematika dengan Menggunakan Pembelajaran Generatif (Generative Learning) di SMP. EDU-MAT Jurnal Pendidikan Matematika, Volume 3, Nomor 2, Oktober 2015, hlm 166 - 175

Soemarmo, $\mathrm{U}$ dan Hendriana, $\mathrm{H}$. (2014). Penilaian Pembelajaran Matematika. Bandung: PT Refika Aditama

Sofan Amri, dkk. (2010). Proses Pembelajaran Kreatif dan Inovatif dalam Kelas. Jakarta: Prestasi Pustaka

Sriyanti. (2019). Evaluasi Pembelajaran Matematika. STKIP Subang. [belum diterbitkan]

Suci Ariani, dkk. (2017). Kemampuan Pemecahan Masalah Matematika Siswa pada Pembelajaran Matematika Menggunakan Strategi Abduktif-Deduktif di SMA Negeri 1 Indralaya Utara. Jurnal Elemen vol 3 no 1, h.28. [Online]. Tersedia: https://ejournal.hamzanwadi.ac.id/index.ph p/jel/article/download/304/pdf 50 . 
Diakses pada tanggal 31 Oktober 2020

Sugiyono, 2015. Metode Penelitian Kombinasi. Bandung: Alfabeta CV

Sugiyono. 2010. Metode Penelitian Kuantitatif Kualitatif dan $R \& D$. Bandung: Alfabeta CV

Surat Edaran Nomor 3 dan 4 Tahun 2020 Tentang Pelaksanaan Pendidikan dalam Masa Darurat Covid. 2020

Susanto, A. (2013). Teori Belajar dan Pembelajaran di Sekolah Dasar. Jakarta: Prenada Media Group

Susilawati, Desi. (2009). Upaya Meningkatkan Kemandirian Belajar dan Kemampuan Matematika Siswa Kelas X SMAN 1 Gamping dengan Menggunakan Lembar Kerja Siswa. Yogyakarta: UNY

Tatang.(2016). Illmu Pendidikan. Bandung: Pustaka Setia

Teguh, Widodo. (2012). Peningkatan Kemandirian Belajar PKN Melalui Model Problem Solving Menggunakan Metode Diskusi pada Siswa Kelas $V$ SDN Rajowinangun III Kota Gede Yogyakarta. S1 Thesis. Universitas Negeri Yogyakarta. [Online]. Tersedia:

https://eprint.uny.ac.id/9567/.

Diakses pada tanggal 28 Juli 2020

Wardhani, dkk. (2010). Pembelajaran Kemampuan Pemecahan Masalah
Matematika di SMP. Yogyakarta: PPTK Matematika

Widarto. (2013). Penelitian Ex Post Facto. Pelatihan Metodologi Penelitian Pendidikan Fakultas Teknik Universitas Negeri Yogyakarta. [Online]. Tersedia: http://repository.upi.edu. Diakses pada tanggal 9 Agustus 2020

Wijaya, A. (2017). Pendidikan Matematika Realistik Suatu Alternatif Pendekatan Pembelajaran Matematika, Yogyakarta: Graha IImu.

Wikipedia. Subjek Hilang. [Online]. Tersedia:

http://em.m.wikipedia.org/wiki/Missi ng data. Diakses pada tanggal 30 Oktober 2020

Zaini, H. (2015). Karakteristik Kurikulum 2013 dan Kurikulum Tingkat Satuan Pendidikan (KTSP). Jurnal Idaroh. Vo. 1 No.1. [Online]. Tersedia: https://jurnal.radenfatah.ac.id . Diakses pada 11 Juni 2020 